\title{
Decreasing particle number concentrations in a warming atmosphere and implications
}

\author{
F. Yu ${ }^{1}$, G. Luo ${ }^{1}$, R. P. Turco ${ }^{2}$, J. A. Ogren ${ }^{3}$, and R. M. Yantosca ${ }^{4}$ \\ ${ }^{1}$ Atmospheric Sciences Research Center, State University of New York at Albany, Albany, New York, USA \\ ${ }^{2}$ Department of Atmospheric and Oceanic Sciences, University of California at Los Angeles, Los Angeles, California, USA \\ ${ }^{3}$ Global Monitoring Division (GMD), Earth System Research Laboratory (ESRL), NOAA, Boulder, Colorado, USA \\ ${ }^{4}$ School of Engineering and Applied Sciences, Harvard University, Boston, Massachusetts, USA
}

Correspondence to: F. Yu (fangqun.yu@asrc.albany.edu)

Received: 22 August 2011 - Published in Atmos. Chem. Phys. Discuss.: 14 October 2011

Revised: 30 January 2012 - Accepted: 23 February 2012 - Published: 5 March 2012

\begin{abstract}
New particle formation contributes significantly to the number concentration of condensation nuclei $(\mathrm{CN})$ as well as cloud $\mathrm{CN}(\mathrm{CCN})$, a key factor determining aerosol indirect radiative forcing of the climate system. Using a physics-based nucleation mechanism that is consistent with a range of field observations of aerosol formation, it is shown that projected increases in global temperatures could significantly inhibit new particle, and $\mathrm{CCN}$, formation rates worldwide. An analysis of $\mathrm{CN}$ concentrations observed at four NOAA ESRL/GMD baseline stations since the 1970s and two other sites since 1990s reveals long-term decreasing trends that are consistent in sign with, but are larger in magnitude than, the predicted temperature effects. The possible reasons for larger observed long-term $\mathrm{CN}$ reductions at remote sites are discussed. The combined effects of rising temperatures on aerosol nucleation rates and other chemical and microphysical processes may imply substantial decreases in future tropospheric particle abundances associated with global warming, delineating a potentially significant feedback mechanism that increases Earth's climate sensitivity to greenhouse gas emissions. Further research is needed to quantify the magnitude of such a feedback process.
\end{abstract}

\section{Introduction}

Atmospheric particles affect the Earth's energy budget directly by scattering solar radiation, and indirectly by acting as cloud condensation nuclei $(\mathrm{CCN})$, which affect cloud optical properties and influence precipitation (e.g., Twomey, 1977). The magnitude of aerosol indirect radiative forcing is poorly constrained in climate models, and represents one of the greatest remaining uncertainties in assessing climate change (IPCC, 2007). A major source of atmospheric CCN is the secondary particle formation frequently observed in the atmosphere (Pierce and Adams, 2007; Makkonen et al., 2009; Wang and Penner, 2009; Yu and Luo, 2009; Spracklen et al., 2010; Kazil et al., 2010). The non-linear dependence of aerosol nucleation rates on key atmospheric parameters, and the influence of aerosol formation on $\mathrm{CCN}$ populations, points to a potentially important climate feedback mechanism involving interactions between particle nucleation, $\mathrm{CCN}$ production, cloud microphysics, and climatic responses.

Ambient atmospheric temperatures $(T)$ and sulfuric acid vapor concentrations $\left(\left[\mathrm{H}_{2} \mathrm{SO}_{4}\right]\right)$ are the dominant factors controlling particle nucleation events in many regional settings (although other parameters, such as relative humidity and ionization rates, can also contribute in determining nucleation rates; e.g., Yu, 2010). In the past, it was suggested that future climatic warming might change oceanic emissions of dimethylsulphide (DMS), thus influencing $\left[\mathrm{H}_{2} \mathrm{SO}_{4}\right]$, sulfate aerosols, and the indirect radiative forcing of marine stratus clouds, defining a climate feedback process (i.e., the CLAW hypothesis; Charlson et al., 1987). After more than two decades of study, however, the strength and even the sign (i.e., negative or positive) of the CLAW feedback process remain ambiguous (e.g., Ayers and Cainey, 2007; Kloster et al., 2007; Woodhouse et al., 2010; Quinn and Bates, 2011). In contrast to the large number of studies considering CLAW ( $\sim 1500$ publications since 1987 , according to Ayers and Cainey, 2007), very few investigations have been carried out 
to quantify the direct effects of climate change (specifically, temperature variations) on new particle and $\mathrm{CCN}$ formation rates, while the associated climate feedback processes, which offer a more direct physical linkage, have never been investigated. Hence, in this study, we seek to quantify the magnitude of a positive climate system feedback involving the influence of temperature on particle nucleation rates. Long term trends in $\mathrm{CN}$ concentrations, derived for the first time from six observational stations with $\sim 15-35 \mathrm{yr}$ records of $\mathrm{CN}$ data, appear to support such a feedback mechanism.

\section{Effect of temperature increase on global particle formation rates and concentrations}

Physically, temperature $(T)$ is a key parameter determining particle nucleation rates $(J)$. Figures 1-2 show the dependence of $J$ on $T$ based on several different nucleation theories. In Fig. 1, the sensitivity of $J$ to $T$ has been determined using a physics-based ion-mediated nucleation (IMN) model that incorporates recently available thermodynamic data (Yu, 2010) and has been tested against detailed multipleinstrument measurements of freshly nucleated particles, including their electrical charge state (Yu and Turco, 2011). The IMN reduces to binary homogeneous nucleation (BHN) (Yu, 2007) when the ionization rate is zero. The percentage change in the nucleation rate $(J)$ (i.e., $\mathrm{PC}_{J}$ ) per degree increase in $T$ is a non-linear function of temperature. IMN rates are very sensitive to temperature as J-values increase from insignificant $\left(<\sim 0.01 \mathrm{~cm}^{-3} \mathrm{~s}^{-1}\right)$ to significant $\left(>\sim 1 \mathrm{~cm}^{-3} \mathrm{~s}^{-1}\right)$. At $J=0.5 \mathrm{~cm}^{-3} \mathrm{~s}^{-1}$, under the conditions considered in Fig. 1, the values of $\mathrm{PC}_{J}$ based on the IMN model are in the range of $-80--20 \%$ per ${ }^{\circ} \mathrm{C}$. After $J_{\text {IMN }}$ reaches a significant value $\left(\sim 1-20 \mathrm{~cm}^{-3} \mathrm{~s}^{-1}\right)$, further decreases in $T$ (other parameters fixed) have small effects, because nucleation under such conditions is limited by the ionization rate. When $T$ is very low, binary homogeneous nucleation (BHN) becomes dominant and $\mathrm{PC}_{J}$ for IMN approaches that for BHN. Compared to BHN alone, IMN yields larger $\mathrm{PC}_{J}$ at higher ambient temperatures, but smaller values at lower temperatures. If averaged over the entire ambient temperature range of interest, $\mathrm{PC}_{J}$ values for $\mathrm{BHN}$ are greater than those for the integrated IMN mechanism.

Figure 2 shows a similar or larger effect of temperature on nucleation rates based on a different BHN (Vehkamaki et al., 2002) and several ternary homogeneous nucleation (THN) models (Napari et al., 2002; Yu, 2006; Merikanto et al., 2007). The THN model of Napari et al. (2002), now known to overestimate the THN rates significantly (Yu, 2006; Merikanto et al., 2007), gives the largest values of $\mathrm{PC}_{J}$. Some unknown or yet to be established nucleation mechanisms (such as the involvement of amines) may also contribute to the production of new particles in the atmosphere. We expect that such nucleation mechanisms would also be quite sensitive to temperature, as this is a key parameter con-

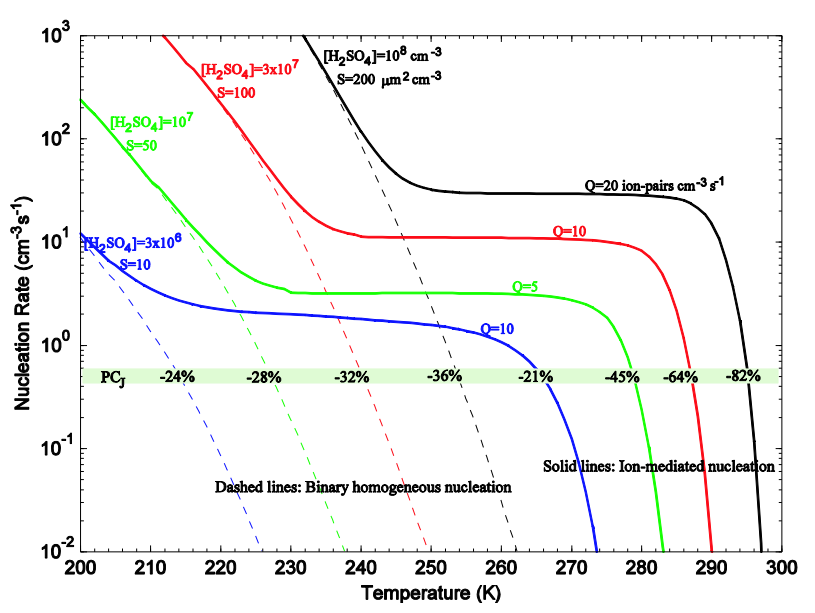

Fig. 1. Dependence of ion-mediated nucleation (IMN) rates (solid lines) and binary homogeneous nucleation (BHN) rates (dashed lines) on temperature $(T)(\mathrm{RH}=50 \%)$. The percentage change (PC) in the nucleation rate $(J)$ per ${ }^{\circ} \mathrm{C}$ increase of $T$ at $J=$ $0.5 \mathrm{~cm}^{-3} \mathrm{~s}^{-1}$ is also given for each case. Lines of same color have same sulfuric acid vapor concentration $\left(\left[\mathrm{H}_{2} \mathrm{SO}_{4}\right]\right.$, in $\left.\mathrm{cm}^{-3}\right)$ and the same local surface area density of pre-existing particles ( $\mathrm{S}$, in $\left.\mu \mathrm{m}^{2} \mathrm{~cm}^{-3}\right)$. IMN rates also depend on ionization rate $(Q$, in ion-pairs $\left.\mathrm{cm}^{-3} \mathrm{~s}^{-1}\right)$. BHN is an integral part of IMN, and $J_{\text {IMN }}$ approaches to $J_{\mathrm{BHN}}$ at low temperatures when BHN is dominant.

trolling the saturation vapor pressures of precursors, stability of pre-nucleation clusters, and thus nucleation rates. As can be seen from Figs. 1 and 2, parameters other than $T$ also have a strong impact on nucleation rates and $\mathrm{PC}_{J}$ values. It should be noted that the dependence of nucleation rates derived from field measurements on temperature may be not as strong as those shown in Figs. 1 and 2 (Mikkonen et al., 2011; Hamed et al., 2007), likely as a result of changes in other key variables (such as $\left[\mathrm{H}_{2} \mathrm{SO}_{4}\right]$ ) that are correlated with $T$, or limitations to nucleation related to other factors under local conditions.

In order to isolate the temperature effect and confidently assess the significance of the temperature feedback mechanism associated with new particle formation and $\mathrm{CCN}$ evolution, a global aerosol model that can treat particle microphysical processes - especially nucleation and growth - is essential. Baseline aerosol simulations should also be carefully validated against observational data. Yu and Luo (2009) incorporated an advanced particle microphysics (APM) model into GEOS-Chem, a global 3-D model of atmospheric composition driven by assimilated meteorological data from the NASA Goddard Earth Observing System 5 (GEOS-5). The GEOS-Chem model has been developed and used by many research groups and contains a number of state-of-the-art modules treating various chemical and aerosol processes (e.g., Bey et al., 2001; Liu et al., 2001; Martin et al., 2003; Park et al., 2004; Evans and Jacob, 2005; Liao et al., 2007; Fountoukis and Nenes, 2007; Trivitayanurak et al., 2008; 

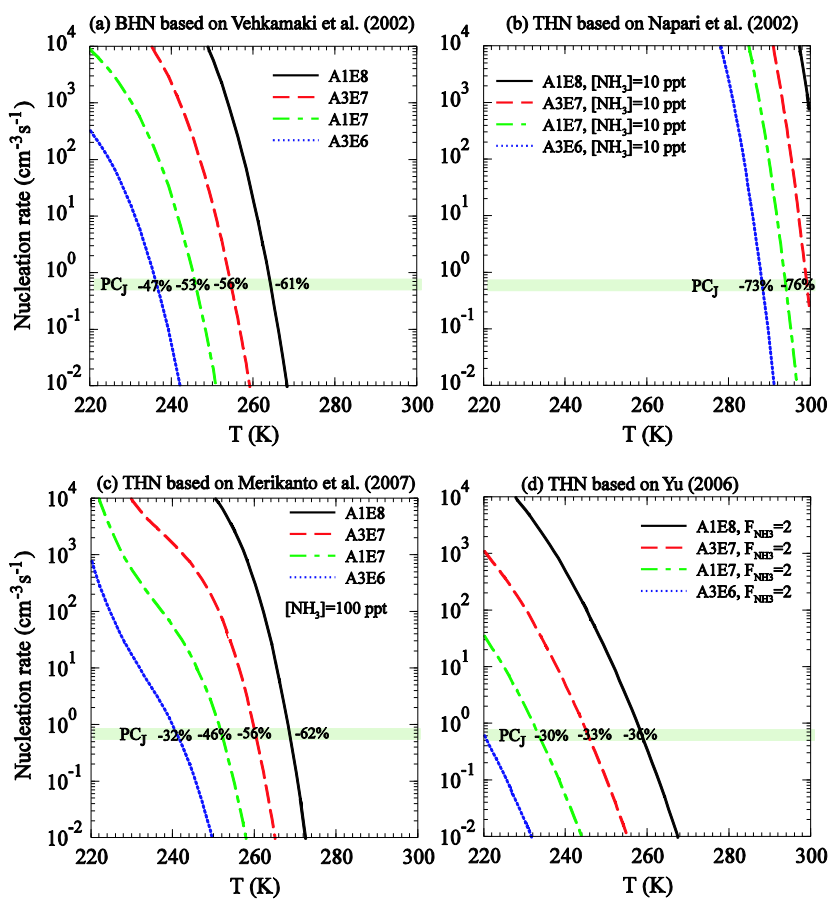

Fig. 2. Effect of temperature $(T)$ on $\mathrm{H}_{2} \mathrm{SO}_{4}-\mathrm{H}_{2} \mathrm{O}$ binary homogeneous nucleation (BHN) and $\mathrm{H}_{2} \mathrm{SO}_{4}-\mathrm{H}_{2} \mathrm{O}-\mathrm{NH}_{3}$ ternary homogeneous nucleation (THN) under a range of atmospheric conditions based on different nucleation models: (a) classical BHN model of Vehkamaki et al. (2002); (b) classical THN model of Napari et al. (2002) with $\left[\mathrm{NH}_{3}\right]=10 \mathrm{ppt}$; (c) revised classical THN model of Merikanto et al. (2007) with $\left[\mathrm{NH}_{3}\right]=100 \mathrm{ppt}$; (d) Kinetic THN model of $\mathrm{Yu}$ (2006) with ammonia stabilizing factor $\left(F_{\mathrm{NH}_{3}}\right)$ constrained by experimental results. In the legend, read A1E8 as $\left[\mathrm{H}_{2} \mathrm{SO}_{4}\right]=1.0 \times 10^{8} \mathrm{~cm}^{-3}$. The percentage change (PC) in the nucleation rate $(J)$ per degree increase in $T$ at $J=0.5 \mathrm{~cm}^{-3} \mathrm{~s}^{-1}$ is also given for each case.

Henze et al., 2008; Yu and Luo, 2009) with up-to-date key emission inventories (e.g., Guenther et al., 2006; Bond et al., 2007; Zhang et al., 2009). The APM model in GEOSChem is optimized to accurately simulate the formation of secondary particles and their growth to CCN sizes, with high size resolution for particles in the size range of $1.2-120 \mathrm{~nm}$ (Yu and Luo, 2009). Our previous validation studies indicate that the predicted total particle number concentrations (with diameters larger than $\sim 3 \mathrm{~nm}$, and $\sim 10 \mathrm{~nm}$ ) agree quite well (generally within a factor of two) with a comprehensive set of land-, ship-, and aircraft- based measurements (Yu and Luo, 2009; Yu et al., 2010; Luo and Yu, 2011).

The results presented below are based on a one-year simulation (October 2004-December 2005, with the first 3 months as spin-up) using GEOS-Chem v8-02-04 + APM, with nucleation rates predicted by the IMN mechanism (Yu, 2010) and the condensation of low volatile secondary organic gases from successive oxidation aging (Yu, 2011) taken into account. The horizontal resolution is $2^{\circ} \times 2.5^{\circ}$ and there are 47 vertical layers in the model (surface to $0.01 \mathrm{hpa}$ ). To estimate temperature sensitivity, two runs were intercompared; one using baseline temperatures, and a second with all temperatures incremented by $1{ }^{\circ} \mathrm{C}$; differencing the results provides the sensitivity per ${ }^{\circ} \mathrm{C}$ around the baseline climate state. The effects of a $1{ }^{\circ} \mathrm{C}$ temperature increase are limited to the calculations of nucleation rates. In the real atmosphere, global temperature change is inhomogeneous and has many other associated changes (meteorological fields, emissions, chemistry, etc.). The sensitivity study presented here is aimed to isolate and illustrate the impact of temperature change on nucleation and particle number concentrations.

Figure 3 illustrates the horizontal (i.e., averaged within a $0-2 \mathrm{~km}$ surface layer) and vertical (i.e., zonally averaged) spatial distributions of annual mean percentage change (PC) in the nucleation rate and $\mathrm{CN} 10$ (i.e., total number of particles larger than 10 -nm diameter) concentrations per ${ }^{\circ} \mathrm{C}$. It is clear from Fig. 3 that, throughout most of the troposphere, annual mean nucleation rates decrease by $\sim 3-30 \%$ for each ${ }^{\circ} \mathrm{C}$ of warming. The maximum decrease can reach values exceeding $30 \%{ }^{\circ} \mathrm{C}^{-1}$ in the tropical lower troposphere, where $T$ is high and $J$ is small, consistent with the dependence of $\mathrm{PC}_{J}$ on $T$ shown in Fig. 1. Figure $3 \mathrm{~b}$ indicates that the regions where large decreases in $J$ occur extend from the surface up to $\sim 400 \mathrm{mb}$ in the tropics $\left(30^{\circ} \mathrm{S}-30^{\circ} \mathrm{N}\right)$. The relatively lower sensitivity of $J$ to $T$ over Antarctica and in the upper troposphere is a result of very cold temperatures, such that nucleation is more strongly limited by $\left[\mathrm{H}_{2} \mathrm{SO}_{4}\right]$ in these regions.

Figure $3 \mathrm{c}$ and $\mathrm{d}$ indicate that, as a result of the reduced nucleation rates, the annual mean $\mathrm{CN} 10$ concentrations decrease by $\sim 2-8 \%$ per ${ }^{\circ} \mathrm{C}$ of warming in most of the troposphere. Similar to the sensitivity of $J$, the maximum decrease in $\mathrm{CN} 10$ occurs in the tropical regions, and can exceed $10 \%$. The zonally-averaged decreases in $\mathrm{CN} 10$ per degree of warming (Fig. 3d) are largest in the tropical lower troposphere (to $5 \%$ or more). The effect of increasing $T$ on $\mathrm{CN} 10$ concentrations is relatively small in the polar regions and in the tropical upper troposphere.

Global surface temperatures have increased at a rate of $\sim 0.17^{\circ} \mathrm{C}$ decade $^{-1}$ on average since the 1970 s, varying from -0.25 to $+0.75^{\circ} \mathrm{C}_{\text {decade }}{ }^{-1}$ in different regions (IPCC, 2007). According to the present results, such long-term trends should have led to noticeable changes in nucleation rates and $\mathrm{CN} 10$ abundances. As it happens, beginning in the middle/late 1970s, NOAA/ESRL's Global Monitoring Division (GMD) has collected long-term measurements of $\mathrm{CN}$ at four remote baseline stations at Barrow, Alaska (BRW), Mauna Loa Observatory, Hawaii (MLO), American Samoa (SMO), and South Pole Observatory (SPO) (Bodhaine, 1983). To our knowledge, BRW, MLO, SMO, and SPO are the only 4 stations around the globe having more than $20 \mathrm{yr}$ of $\mathrm{CN}$ data available in the public domain that allow one to look into the long-term trends of atmospheric 
(a) Annual mean horizontal $(0-2 \mathrm{~km}) \mathrm{PC}_{\lrcorner}$

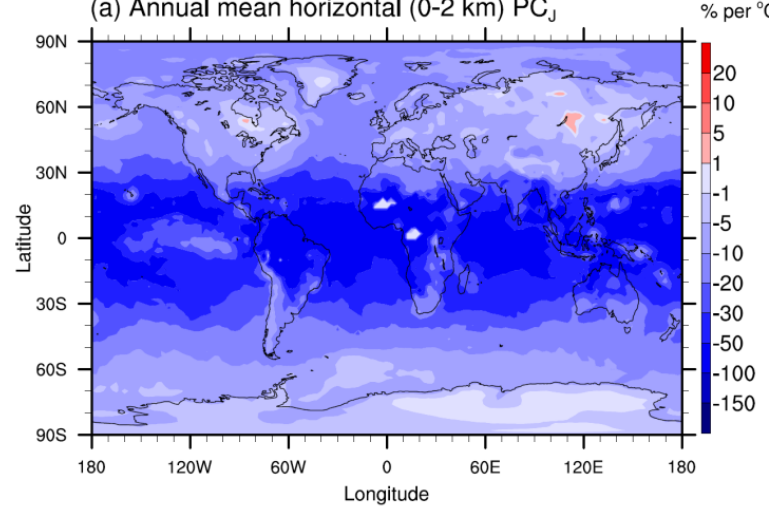

(c) Annual mean horizontal (0-2 km) $\mathrm{PC}_{\mathrm{CN} 10}$

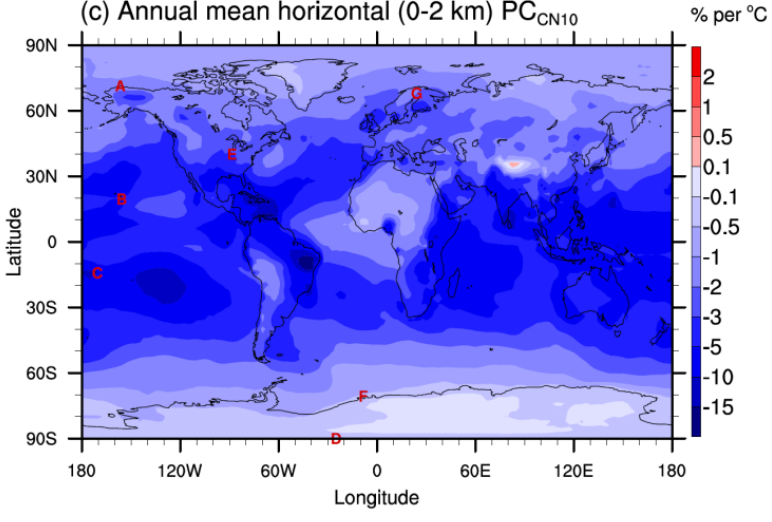

(b) Annual mean vertical $\mathrm{PC}_{\mathrm{J}}$

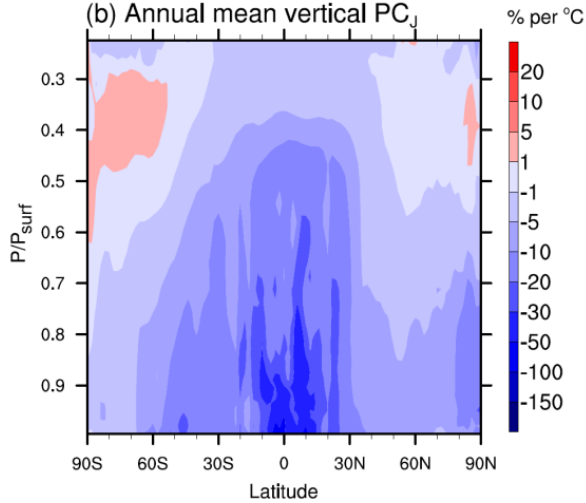

(d) Annual mean vertical $\mathrm{PC}_{\mathrm{CN} 10} \quad \%$ per ${ }^{\circ} \mathrm{C}$

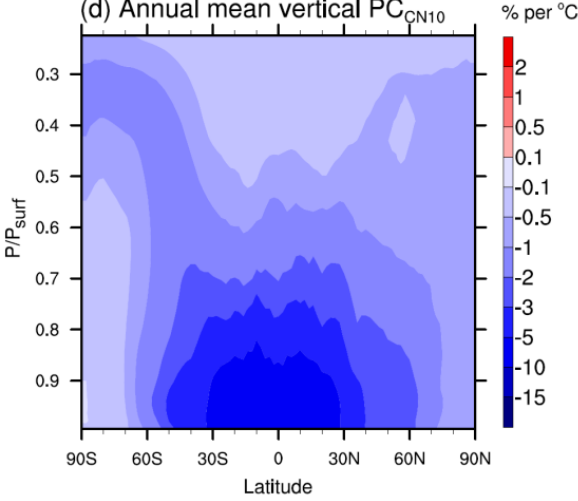

Fig. 3. Horizontal (i.e., averaged within the $0-2 \mathrm{~km}$ surface layer) and vertical (i.e., zonally averaged) spatial distributions of the annual mean percentage changes in nucleation rates $(J)$ and concentrations of condensation nuclei larger than $10 \mathrm{~nm}(\mathrm{CN} 10)$, for a uniform $1{ }^{\circ} \mathrm{C}$ temperature increase. These temperature sensitivities were calculated as described in the text. In panel (c), the locations of four NOAA baseline stations (BRW, MLO, SMO, and SPO), one NOAA regional station (BND), and one German Antarctic station (NEU) are marked respectively as A, B, C, D, E, and F. The location of Pallas station discussed in Supplement is marked as G.

particle number concentrations. It should be noted that the Australian "Atmospheric Baseline" program began $\mathrm{CN}$ measurements at Cape Grim $\left(40.7^{\circ} \mathrm{S}, 144.7^{\circ} \mathrm{E}\right)$ in the latter 1970s (Gras, 1990) but the long-term Cape Grim CN data are not yet available. The GMD has another site at Bondville, Illinois (BND) which has recorded CN values since 1994 . In addition, the German Antarctic station Neumayer (NEU) has measured CN since 1993 (Weller and Lampert, 2008). The Switzerland Jungfraujoch High-Alpine Research Station (3580 m a.s.1.) has obtained CN data since 1995.

Figure 4 illustrates the monthly and annual mean $\mathrm{CN}$ values observed at four NOAA baseline stations as well as BND and NEU (at locations marked respectively as A, B, C, D, E, and F in Fig. 3c) sites, along with linear regression (LR) results based on annual mean $\mathrm{CN}$ data. The multiple-year mean CN values, Pearson's product moment correlation coefficients $(r)$, and slopes (with $95 \%$ confidence intervals for the regression lines) are given in the figure legends. It should be noted that 30 plus years of CN data for BRW, MLO, and SMO during different periods were obtained using two or three different $\mathrm{CN}$ counters (with $50 \%$ particle detec- tion efficiency diameters varying from $\sim 8 \mathrm{~nm}$ to $\sim 12 \mathrm{~nm}$ and $\sim 15 \mathrm{~nm}$ ). The supporting analysis provided in the Supplement shows that the changeover of $\mathrm{CN}$ counters is likely to have had only a small (< $<\%)$ effect on the variance of $\mathrm{CN}$ values at these three remote sites. Only the most recent $22 \mathrm{yr}$ of measurements from SPO are included in this study, as explained in the Supplement, an unexplained increase in $\mathrm{CN}$ concentrations associated with a change in the $\mathrm{CN}$ counter in 1989 hinders the interpretation of the entire record there as a continuous time series.

Although there exist substantial inter-annual variations (likely as a result of El Nino, interannual and decadal dynamics, volcanic eruptions, biomass burning, and so on) and some periods of missing data, $\mathrm{CN}$ concentrations exhibit a long-term decreasing trend at each of the six sites: $-40.4 \%$, $-14.5 \%,-13.9 \%,-14.3 \%,-3.3 \%$, and $-26.3 \%$ per decade at BRW, BND, MLO, SMO, NEU and SPO, respectively. Based on linear correlation coefficients and $95 \%$ confidence intervals for slopes, the decreasing trends are statistically significant at the BRW, MLO, SMO, and SPO sites, but are not significant at the BND and NEU sites. It is interesting 

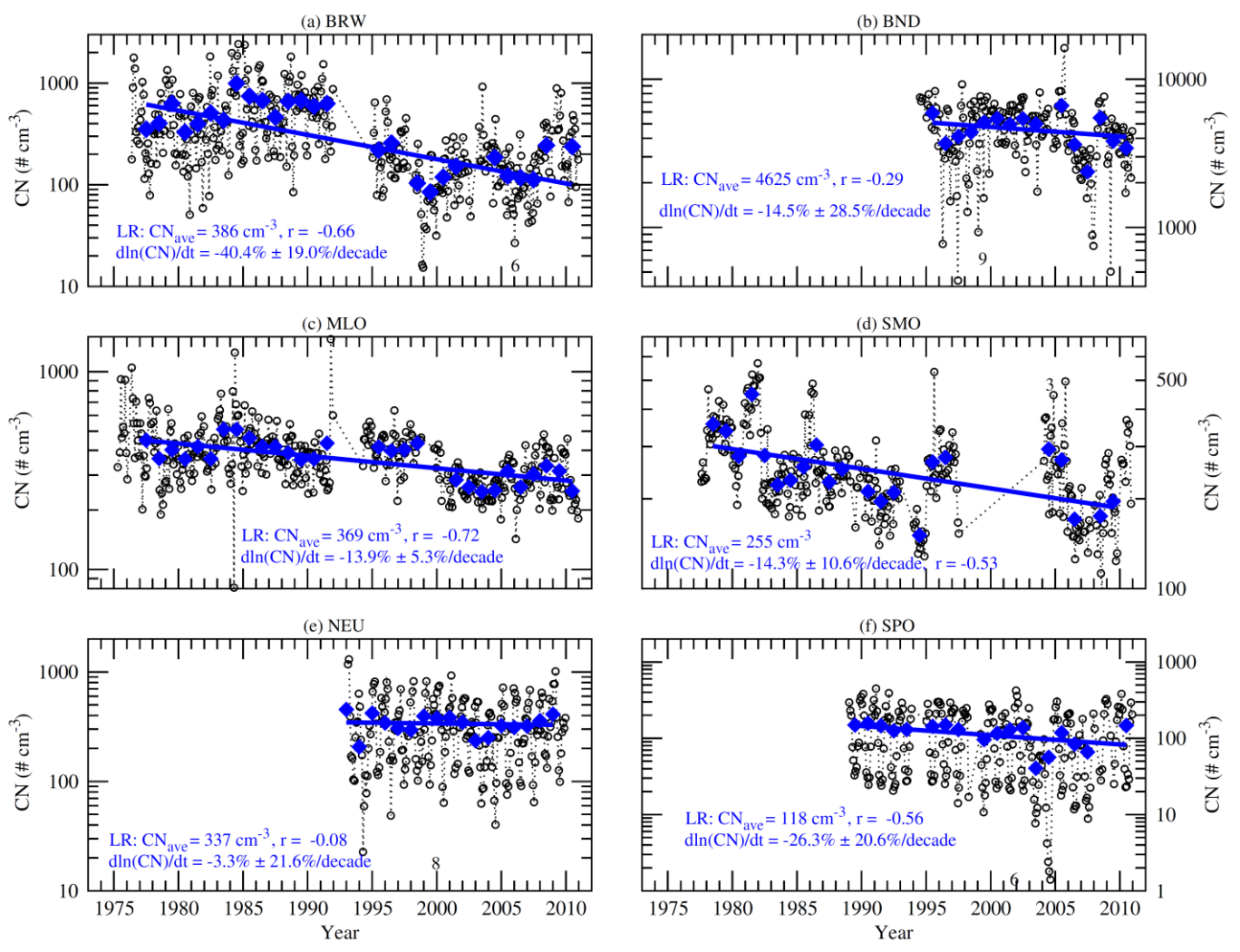

Fig. 4. Annual (filled diamonds) and monthly (open circles) mean CN values observed at the five NOAA sites and one German Antarctic station identified in Fig. 3c. Annual mean values are shown for years with at least 10 months of monthly mean data. In the figure, linear regressions (LR) are derived from the annual mean $\mathrm{CN}$ observations, and the corresponding mean $\mathrm{CN}$ values, Pearson's product moment correlation coefficients $(r$ ), and slopes (with $95 \%$ confidence intervals for the regression slopes) are given in the legend.

to note that both the BND and NEU sites have only $\sim 15 \mathrm{yr}$ of $\mathrm{CN}$ data. Our statistical analysis may indicate that, due to the relatively small long-term trends compared to inter-annual variations, 20 or more years of data are needed to derive statistically significant trends. For BRW, MLO, and SMO, which have more than $\sim 30 \mathrm{yr}$ of data, there are extended periods (lasting several years) where data are missing. While these gaps may increase the uncertainty in derived trends, it is unlikely that significant systematic shifts had occurred during these isolated, random periods where data are missing. We could not find any records of changes in instrumentation or measurement technique, sampling strategy or location, or other factors that might have led to systematic biasing of the data only during the gaps. At Barrow, most of the decline in $\mathrm{CN}$ concentrations appears to have occurred during a period (1992-1994) when no observations were recorded. It is therefore difficult in this case to determine whether the $\mathrm{CN}$ decrease may have actually been related to a reconfiguration of the instrumentation or calibration; the literature is not definitive in this regard. As can be seen in Fig. 4, changes of a similar magnitude over periods of several years are not uncommon due to inter-annual variability, while there are also no obvious changes in observed $\mathrm{CN}$ values during the extended periods of missing data at MLO and SMO. In addition, the decrease in $\mathrm{CN}$ from $\sim 1990$ to 1995 at Barrow coincides with the substantial reduction in $\mathrm{SO}_{2}$ emissions in North America associated with Clean Air Act in the US. It should be noted that the conclusions of this paper rely more heavily on observations at other NOAA sites (MLO, SMO, SPO), where the effect of missing data appears to be smaller.

Both surface and tropospheric air temperatures trended upward during the last 3-4 decades in the regions around $\mathrm{BRW}$, BND, MLO, and SMO, in the range of 0.15$0.55^{\circ} \mathrm{C} \mathrm{decade}^{-1}$ (IPCC, 2007). Temperatures increase in some regions, and decrease in others around NEU and $\mathrm{SPO}$, ranging from $-0.25^{\circ} \mathrm{C}$ decade $^{-1}$ to $+0.25^{\circ} \mathrm{C}$ decade $^{-1}$ (IPCC, 2007). The opposing observed long-term trends in $T$ and $\mathrm{CN}$ appear to be consistent with the physics of nucleation and particle evolution (Figs. 1-3). It should be noted that tropospheric particles have lifetimes of $\sim 1$ week, and thus $\mathrm{CN}$ are subject to the influence of variations in temperatures and nucleation rates in regions upwind of measurement sites. We would like to emphasize that the values of above derived $\mathrm{CN}$ trends are subject to uncertainty associated with $\mathrm{CN}$ counting efficiency, instrument operation condition, and missing data. Nevertheless, Fig. 4 represents the best set of 
long-term $\mathrm{CN}$ data presently available and our analysis indicates that, thanks to the relatively long duration of the data, a few short periods of abnormal values do not change the overall decreasing trends of $\mathrm{CN}$ concentrations.

The observed long-term trends in $\mathrm{CN}$ at the 6 sites shown in Fig. 4 are generally larger than would be expected from the effects of temperature changes alone (Fig. 3c). A number of possible mechanisms may contribute to this result, including but not limited to: (1) changes in anthropogenic emissions of particles and their precursors over time; (2) variations and trends in the natural emission rates of particles and precursors; (3) shifts in the chemical balance of the troposphere; and (4) changes in meteorological factors (precipitation, wind speed, boundary layer depth, etc.). For example, the changes in anthropogenic $\mathrm{SO}_{2}$ emissions in the Eurasia and US may have contributed to incremental decreases in $\mathrm{CN}$ at BRW. The reduction in anthropogenic $\mathrm{SO}_{2}$ emissions may also have contributed to the decreasing trend in $\mathrm{CN}$ at BND. At more remote MLO, SMO, NEU, and SPO sites, oceanic DMS emissions are likely to be the major sulfur source but some anthropogenic influences on $\mathrm{CN}$ would be expected as well. As mentioned earlier, the response of oceanic DMS emissions to global climate change, and hence the sign of the CLAW feedback process, remains undetermined. A number of recent studies indicate that global warming may actually stratify the ocean surface, limit nutrient supply, and thus reduce DMS emission, in which case the feedback loop becomes positive (so-called "positive-CLAW") (e.g., Kloster et al., 2007; Ayers and Cainey, 2007). As far as we know, no long-term measurements of DMS or $\mathrm{SO}_{2}$ concentrations exist that can be used to accurately quantify the trend in DMS emission over the last several decades. The long-term CN data measured at remote oceanic sites might be a suitable indicator of how DMS emissions have changed in the past. For such a purpose, further research would be needed to understand the sensitivity of $\mathrm{CN}$ values at remote sites to long-term changes in anthropogenic and natural emissions and key meteorological parameters, which is beyond the scope of this paper.

\section{Effect of temperature increase on $\mathrm{CCN}$ concentrations}

It is shown above that global warming could slow down new particle formation and reduce total particle number concentrations. However, to assess the climatic impact of this mechanism, the effect on CCN concentrations must be determined, which depends not only on nucleation rates, but also on the growth rates of nucleated particles and the sources of primary particles that can act as cloud nuclei. In this regard, a global model that is capable of reproducing baseline ambient distributions of observed primary and secondary $\mathrm{CCN}$ is necessary. Toward this end, simulations with the modeling system described above are presented in Fig. 5. Fig- ure 5a shows the simulated spatial distribution of the annual mean number concentrations of CCN (defined at a water supersaturation of $0.4 \%-\mathrm{CCN} 0.4)$ averaged within the lower boundary layer $(0-0.4 \mathrm{~km})\left([\mathrm{CCN} 0.4]_{\mathrm{LBL}}\right)$. Figure $5 \mathrm{~b}$ compares simulated [CCN0.4] LBL values with those observed at 26 stations around the globe. The locations of the 26 stations are indicated by the letters in Fig. 5a. The CCN0.4 data include those compiled by Andreae (2009), with additional data points taken from recent publications (Dal Maso et al., 2008; Bougiatioti et al., 2009; Hudson and Noble, 2009; Komppula et al., 2009; Kivekas et al., 2009), as well as archival observations (DOE's Atmospheric System Research). In some locations, multiple CCN data are available for different seasons, and averaged values were used for the comparisons. In the model employed here, $\mathrm{CCN}$ concentrations are calculated at the prescribed supersaturation based on the simulated particle size distributions and compositions, using the scheme of Petters and Kreidenweis (2007). It should be noted that the model results in Fig. 5a are annual mean values, while most of the $\mathrm{CCN}$ data are from various field campaigns that lasted a few weeks to months. Owing to large seasonal variations, model results corresponding to the months of the observations are used for comparisons with observations in Fig. 5b. The vertical bars in Fig. 5b define the simulated ranges of monthly mean $\mathrm{CCN}$ values.

Figure $5 \mathrm{~b}$ shows that the simulated CCN0.4 values agree reasonably well with surface-based observations obtained at different points on the globe (within a factor of $\sim 2$ for all sites), keeping in mind limitations in the CCN0.4 data with respect to regional representation and duration of observations. Overall, the simulations capture the absolute values as well as the horizontal variations of the observed [CCN0.4] at the 26 sites worldwide, with an overall correlation coefficient $(r)$ of 0.94 and a normalized mean bias (NMB) of $0.78 \%$. [CCN0.4 $]_{\mathrm{LBL}}$ ranges from several-tens $\mathrm{cm}^{-3}$ in remote oceanic areas to several-thousands $\mathrm{cm}^{-3}$ over polluted regions, with the highest annual mean value exceeding $4000 \mathrm{~cm}^{-3}$ in the lower boundary layer over East Asia. Due to large anthropogenic sources over major continents in the Northern Hemisphere, [CCN0.4 $]_{\text {LBL }}$ values are roughly a factor of two or more larger than corresponding levels in the Southern Hemisphere. As a result of continental outflows, the [CCN0.4] distribution has large horizontal gradients in coastal areas, and enhanced [CCN0.4] zones can be seen over some regions of the oceans. [CCN0.4 $]_{\mathrm{LBL}}$ over the North Atlantic exceeds $100 \mathrm{~cm}^{-3}$, although it is generally below $\sim 100 \mathrm{~cm}^{-3}$ elsewhere in the marine boundary layer. [CCN0.4 $]_{\text {LBL }}$ over the polar regions are generally below $\sim 150 \mathrm{~cm}^{-3}$ and comparable to those over the remote oceans.

With the GEOS-Chem + APM model, which generally captures the absolute values as well as the spatial variations in the observed $\mathrm{CCN}$ distribution, the sensitivity to changes in nucleation rates associated with global warming can be investigated. Figure 6 shows the changes in [CCN0.4] 
(a) Annual mean horizontal (0-0.4 km) CCN0.4

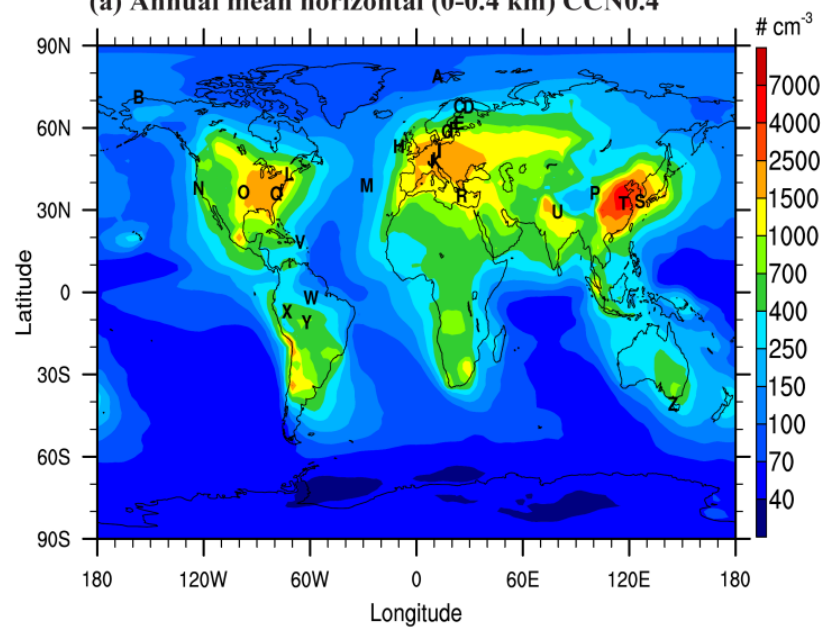

(b) Simulated versus observed CCNO.4

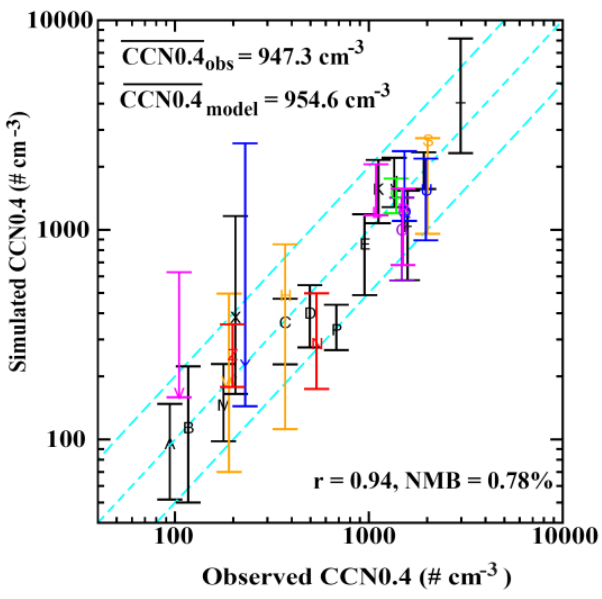

Fig. 5. (a) Simulated global distribution of $\mathrm{CCN}$ concentrations (annual mean number concentration for CCN that are active at a water supersaturation of $0.4 \%)$ averaged within the lower boundary layer $(0-0.4 \mathrm{~km})$ (designated as $\left.[\mathrm{CCN} 0.4]_{\mathrm{LBL}}\right)$. (b) Comparison of simulated $[\mathrm{CCN} 0.4]_{\text {LBL }}$ with observed values at 26 sites around the globe (locations are indicated in Fig. 5a by letters). In Fig. 5b, model results correspond to the months of the observations, and vertical bars define the simulated ranges of monthly mean CCN0.4 values. In Fig. $5 \mathrm{~b}$, the site identifier and bars indicating variance are color coded for clarity.

associated with increasing temperatures $\left(\%{ }^{\circ} \mathrm{C}^{-1}\right)$ in the lower troposphere $(0-2 \mathrm{~km})$, and the scaled total CCN0.4 change projected to the end of the century (2080-2099) based on NCAR CCSM3 global warming predictions corresponding to the IPCC-DDC 4th Assessment Report Scenario SR-A1B. Figure 6a indicates that, as the result of a decrease in nucleation rates, annual mean CCNO.4 concentrations decrease by $\sim 1-3 \%$ per degree of warming through most of the troposphere. In contrast to $J$ and $\mathrm{CN} 10$, which show a maximum decrease in the tropics, $\mathrm{PC}_{\mathrm{CCN} 0.4}$ has large values in regions where particle growth rates are normally fast (associated with anthropogenic and biogenic precursor emissions). The maximum decrease in CCN0.4 exceeds $3 \%{ }^{\circ} \mathrm{C}^{-1}$ over South America and India. The zonally averaged (not shown) decreases in CCN0.4 are largest in the tropical lower troposphere (reaching above $2 \%{ }^{\circ} \mathrm{C}^{-1}$ ).

Global climate models project significant greenhouse warming by the end of this century, with large uncertainties and spatial variations (IPCC, 2007). Figure 6b offers an example of how such warming might impact $\mathrm{CCN}$ abundances in different regions as a result of direct temperature effects on nucleation rates. Figure $6 \mathrm{~b}$ suggests that the impact of global warming (according to NCAR CCSM3 Scenario SR-A1B forecasts, IPCC 2007) based on the positive feedback mechanism quantified above (with no other specified changes in emissions, or other factors) could result in a decrease in CCN0.4 of up to 5-10\% over many continental landmasses. The estimated decrease in CCNO.4 is greatest in the Arctic and over major continents because of large increases in temperatures, and/or high sensitivity of CCNO.4 to temperature change, predicted for these regions. It should be emphasized that Fig. $6 \mathrm{~b}$ represents the scaled CCN change using the CCSM3 projected temperature changes. Under actual conditions, the effect of temperature on $\mathrm{CCN}$ concentrations is likely to be more non-linear, involving other factors that also contribute to $\mathrm{CCN}$ production and loss. Nevertheless, Fig. $6 \mathrm{~b}$ highlights the potential importance of accounting for the temperature dependence of new particle formation in projecting future atmospheric aerosol burdens and properties.

\section{Summary and discussion}

The present analysis points to the existence of a positive climate feedback mechanism that involves a decrease in cloud condensation nuclei $(\mathrm{CCN})$ concentrations associated with regional climate warming caused by greenhouse gas emissions. The estimated 1-3\% CCN decrease for each degree Centigrade of regional warming leads to a reduced aerosol indirect radiative cooling effect of clouds that form on the $\mathrm{CCN}$, thus amplifying the initial warming. The feedback mechanism works because the formation of new aerosol particles, a fraction of which eventually evolve into $\mathrm{CCN}$, is suppressed as ambient temperatures rise. It has long been known that $\mathrm{CCN}$ influence cloud microphysical and optical properties in such a way that a decrease in $\mathrm{CCN}$ generally increases the mean size of cloud droplets, reduces cloud albedo, enhances precipitation, and decreases cloud cover (Twomey, 1977; IPCC, 2007). By reducing cloud albedo and area, more solar energy reaches the surface, intensifying the initiating warming - that is, a positive feedback occurs. It should 
(a) $\mathrm{PC}_{\mathrm{CCN} 0.4}$ in LT $(0-2 \mathrm{~km})$

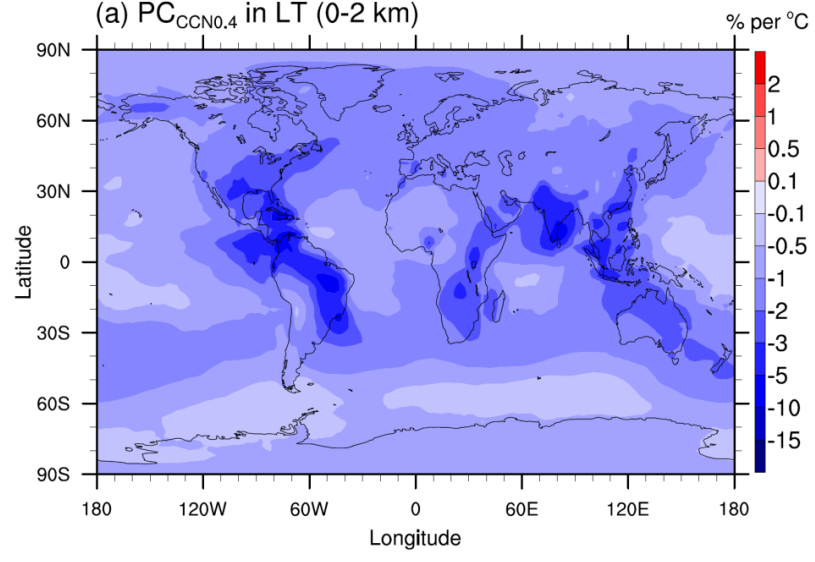

(b) CCNO.4 change in LT (0-2 km) by year 2080-2099

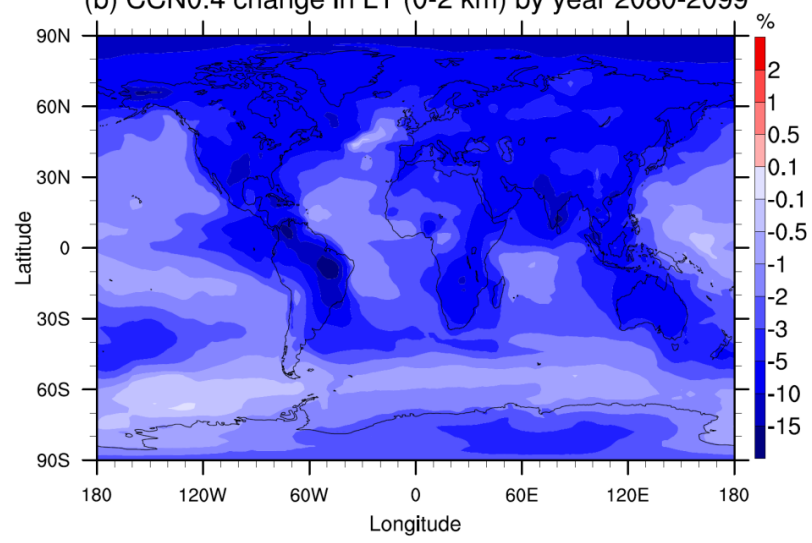

Fig. 6. Sensitivity of CCN0.4 to temperature change $\left(\%\right.$ per $\left.{ }^{\circ} \mathrm{C}\right)$ in the lower troposphere $(0-2 \mathrm{~km})$, and the scaled total CCNO.4 change (\%) toward the end of this century (2080-2099 period) based on NCAR CCSM3 projected global temperature changes corresponding to IPCC-DDC 4th Assessment Report Scenario SR-A1B.

be pointed out that changes in CCN concentrations of only a few percent can have substantial climate forcing implications (Platnick and Twomey, 1994). A rough calculation (Luo and $\mathrm{Yu}, 2011$ ) suggests that a $1 \%$ decrease in $\mathrm{CCN}$ may lead to a positive first-indirect radiative forcing of $\sim 0.1 \mathrm{~W} \mathrm{~m}^{-2}$. Accordingly, the positive feedback process discussed here might contribute an additional forcing of $+0.1-0.3 \mathrm{~W} \mathrm{~m}^{-2}$ per degree of global warming, enough to increase the sensitivity of Earth's climate system significantly.

This analysis only considers the direct effect of increasing temperatures on new particle formation, ignoring other related factors that might play a role; e.g., effects on emissions of aerosol precursor compounds, the hydrological cycle, photochemical reaction rates, oxidant concentrations, gas-particle partitioning, and so on. A global climate model, with relevant key processes reasonably validated, is needed to assess the importance of the positive feedback proposed in this study amid associated changes of these other factors. Nevertheless, the long-term decreasing trends in $\mathrm{CN}$ concentrations, which have been observed at four NOAA ESRL/GMD baseline stations since the 1970s and two other sites since middle 1990s, appear to not only be consistent with the specific positive feedback mechanism outlined in this study, but also indirectly support the idea that feedback processes associated with other related factors affecting $\mathrm{CN}$ are, overall, positive in nature. Taken together, the feedback effects of warming on nucleation rates and other factors would imply a significant decrease in the concentrations of tropospheric particles associated with future climate change. These feedback processes will affect the climate sensitivity of greenhouse gas emissions and should be incorporated in ongoing model assessments of global warming.

\section{Supplementary material related to this article is available online at: http://www.atmos-chem-phys.net/12/2399/2012/ acp-12-2399-2012-supplement.pdf.}

Acknowledgements. This study is supported by NSF under grant AGS-0942106 and NASA under grant NNX11AQ72G. We thank the following sources of information and data used in this work: the Observatory Staff and Aerosol Group of NOAA/ESRL's GMD for making CN measurements available; Rolf Weller of the Alfred Wegener Institute for Polar and Marine Research for the Neumayer $\mathrm{CN}$ data; Anne Jefferson (NOAA/ESRL/GMD and U. Colo/CIRES) for the CCN data observed through the Atmospheric Radiation Measurement (ARM) Program sponsored by the US Department of Energy; the NCAR CCSM3 team for projected temperature increases; and Hatakka Juha of the Finnish Meteorological Institute and the CREATE Aerosol Database for particle size distributions at Pallas used in the Supplement. The GEOS-Chem model is managed by the Atmospheric Chemistry Modeling Group at Harvard University with support from NASA's Atmospheric Chemistry Modeling and Analysis Program.

Edited by: E. Vignati

\section{References}

Andreae, M. O.: Correlation between cloud condensation nuclei concentration and aerosol optical thickness in remote and polluted regions, Atmos. Chem. Phys., 9, 543-556, doi:10.5194/acp-9-543-2009, 2009.

Ayers, G. P. and Cainey, J. M.: The CLAW hypothesis: a review of the major developments, Environ. Chem., 4, 366-374, 2007.

Bey, I., Jacob, D. J., Yantosca, R. M., Logan, J., Field, B., Fiore, A., Li, Q., Liu, H., Mickley, L., and Schultz, M.: Global modeling of tropospheric chemistry with assimilated meteorology: Model description and evaluation, J. Geophys. Res., 106, 23073-23096, 2001.

Bodhaine, B.: Aerosol measurements at four background sites, J. Geophys. Res., 88, 10753-10768, 1983.

Bond, T. C., Bhardwaj, E., Dong, R., Jogani, R., Jung, S., Roden, C., Streets, D. G., and Trautmann, N. M.: Historical emissions of black and organic carbon aerosol from energy related 
combustion, 1850-2000, Global Biogeochem. Cy., 21, GB2018, doi:10.1029/2006GB002840, 2007.

Bougiatioti, A., Fountoukis, C., Kalivitis, N., Pandis, S. N., Nenes, A., and Mihalopoulos, N.: Cloud condensation nuclei measurements in the marine boundary layer of the Eastern Mediterranean: CCN closure and droplet growth kinetics, Atmos. Chem. Phys., 9, 7053-7066, doi:10.5194/acp-9-7053-2009, 2009.

Charlson, R. J., Lovelock, J. E., Andreae, M. O., and Warren, S. G.: Oceanic phytoplankton, atmospheric sulphur, cloud albedo and climate, Nature, 326, 655-661, 1987.

Dal Maso, M., Hyvarinen, A., Komppula, M., Tunved, P., Kerminen, V.-M., Lihavainen, H., Viisanen, Y., Hansson, H.-C., and Kulmala, M.: Annual and interannual variation in boreal forest aerosol particle number and volume concentration and their connection to particle formation, Tellus, 60B, 495-508, 2008.

Evans, M. J. and Jacob, D. J.: Impact of new laboratory studies of $\mathrm{N}_{2} \mathrm{O}_{5}$ hydrolysis on global model budgets of tropospheric nitrogen oxides, ozone, and OH, Geophys. Res. Lett., 32, L09813, doi:10.1029/2005GL022469, 2005.

Fountoukis, C. and Nenes, A.: ISORROPIA II: a computationally efficient thermodynamic equilibrium model for $\mathrm{K}^{+} \mathrm{Ca}^{2+} \mathrm{Mg}^{2+} \mathrm{NH}_{4}^{+} \mathrm{Na}^{+} \mathrm{SO}_{4}^{2-} \mathrm{NO}_{3}^{-} \mathrm{Cl}^{-} \mathrm{H}_{2} \mathrm{O}$ aerosols, Atmos. Chem. Phys., 7, 4639-4659, doi:10.5194/acp-7-4639-2007, 2007.

Gras, J. L.: CN, CCN and particle size in Southern Ocean air at Cape Grim, Atmos. Res., 35, 233-251, 1995.

Guenther, A., Karl, T., Harley, P., Wiedinmyer, C., Palmer, P. I., and Geron, C.: Estimates of global terrestrial isoprene emissions using MEGAN (Model of Emissions of Gases and Aerosols from Nature), Atmos. Chem. Phys., 6, 3181-3210, doi:10.5194/acp-63181-2006, 2006.

Hamed, A., Joutsensaari, J., Mikkonen, S., Sogacheva, L., Dal Maso, M., Kulmala, M., Cavalli, F., Fuzzi, S., Facchini, M. C., Decesari, S., Mircea, M., Lehtinen, K. E. J., and Laaksonen, A.: Nucleation and growth of new particles in Po Valley, Italy, Atmos. Chem. Phys., 7, 355-376, doi:10.5194/acp-7-355-2007, 2007.

Henze, D. K., Seinfeld, J. H., Ng, N. L., Kroll, J. H., Fu, T.-M., Jacob, D. J., and Heald, C. L.: Global modeling of secondary organic aerosol formation from aromatic hydrocarbons: highvs. low-yield pathways, Atmos. Chem. Phys., 8, 2405-2420, doi:10.5194/acp-8-2405-2008, 2008.

Hudson, J. G. and S. Noble: CCN and cloud droplet concentrations at a remote ocean site, Geophys. Res. Lett., 36, L13812, doi:10.1029/2009GL038465, 2009.

IPCC: Climate Change 2007: The physical science Basis, edited by S. Solomon, et al., Cambridge Univ. Press, Cambridge, United Kingdom and New York, NY, USA, 2007.

Kazil, J., Stier, P., Zhang, K., Quaas, J., Kinne, S., O’Donnell, D., Rast, S., Esch, M., Ferrachat, S., Lohmann, U., and Feichter, J.: Aerosol nucleation and its role for clouds and Earth's radiative forcing in the aerosol-climate model ECHAM5-HAM, Atmos. Chem. Phys., 10, 10733-10752, doi:10.5194/acp-1010733-2010, 2010.

Kivekäs, N., Sun, J., Zhan, M., Kerminen, V.-M., Hyvärinen, A., Komppula, M., Viisanen, Y., Hong, N., Zhang, Y., Kulmala, M., Zhang, X.-C., Deli-Geer, and Lihavainen, H.: Long term particle size distribution measurements at Mount Waliguan, a highaltitude site in inland China, Atmos. Chem. Phys., 9, 5461-5474, doi:10.5194/acp-9-5461-2009, 2009.

Kloster, S., Six, K. D., Feichter, J., Maier-Reimer, E., Roeckner, E., Wetzel, P., Stier, P., and Esch, M.: Response of dimethylsulfide (DMS) in the ocean and atmosphere to global warming, J. Geophys. Res., 112, G03005, doi:10.1029/2006JG000224, 2007.

Komppula, M., Lihavainen, H., Hyvärinen, A.-P., Kerminen, V.-M., Panwar, T. S., Sharma, V. P., and Viisanen, Y.: Physical properties of aerosol particles at a Himalayan background site in India, J. Geophys. Res., 114, D12202, doi:10.1029/2008JD011007, 2009.

Liao, H., Henze, D. K., Seinfeld, J. H., Wu, S., and Mickley, L. J.: Biogenic secondary organic aerosol over the United States: Comparison of climatological simulations with observations, J. Geophys. Res., 112, D06201, doi:10.1029/2006JD007813, 2007.

Liu, H., Jacob, D. J., Bey, I., and Yantosca, R. M.: Constraints from ${ }^{210} \mathrm{~Pb}$ and ${ }^{7} \mathrm{Be}$ on wet deposition and transporting a global threee-dimensional chemical tracer model driven by assimilated meteorological fields, J. Geophys. Res., 106, 12109-12128, 2001.

Luo, G. and Yu, F.: Sensitivity of global cloud condensation nuclei concentrations to primary sulfate emission parameterizations, Atmos. Chem. Phys., 11, 1949-1959, doi:10.5194/acp-111949-2011, 2011.

Makkonen, R., Asmi, A., Korhonen, H., Kokkola, H., Järvenoja, S., Räisänen, P., Lehtinen, K. E. J., Laaksonen, A., Kerminen, V.M., Järvinen, H., Lohmann, U., Bennartz, R., Feichter, J., and Kulmala, M.: Sensitivity of aerosol concentrations and cloud properties to nucleation and secondary organic distribution in ECHAM5-HAM global circulation model, Atmos. Chem. Phys., 9, 1747-1766, doi:10.5194/acp-9-1747-2009, 2009.

Martin, R. V., Jacob, D. J., Yantosca, R. M., Chin, M., and Ginoux, P.: Global and regional decreases in tropospheric oxidants from photochemical effects of aerosols, J. Geophys. Res., 108, 4097, doi:10.1029/2002JD002622, 2003.

Merikanto, J., Napari, I., Vehkamäki, H., Anttila, T., and Kulmala, M.: New parameterization of sulfuric acid-ammonia-water ternary nucleation rates at tropospheric conditions, J. Geophys. Res., 112, D15207, doi:10.1029/2006JD007977, 2007.

Mikkonen, S., Korhonen, H., Romakkaniemi, S., Smith, J. N., Joutsensaari, J., Lehtinen, K. E. J., Hamed, A., Breider, T. J., Birmili, W., Spindler, G., Plass-Duelmer, C., Facchini, M. C., and Laaksonen, A.: Meteorological and trace gas factors affecting the number concentration of atmospheric Aitken $\left(D_{\mathrm{p}}=50 \mathrm{~nm}\right)$ particles in the continental boundary layer: parameterization using a multivariate mixed effects model, Geosci. Model Dev., 4, 1-13, doi:10.5194/gmd-4-1-2011, 2011.

Napari, I., Noppel, M., Vehkamäki, H., and Kulmala, M.: Parametrization of ternary nucleation rates for $\mathrm{H}_{2} \mathrm{SO}_{4}-\mathrm{NH}_{3}-\mathrm{H}_{2} \mathrm{O}$ vapors, J. Geophys. Res., 107, 4381, doi:10.1029/2002JD002132, 2002.

Park, R. J., Jacob, D. J., Field, B. D., Yantosca, R. M., and Chin, M.: Natural and transboundary pollution influences on sulfate-nitrate-ammonium aerosols in the United States: Implications for policy, J. Geophys. Res., 109, D15204, doi:10.1029/2003JD004473, 2004.

Petters, M. D. and Kreidenweis, S. M.: A single parameter representation of hygroscopic growth and cloud condensation nucleus activity, Atmos. Chem. Phys., 7, 1961-1971, doi:10.5194/acp-71961-2007, 2007. 
Pierce, J. R. and Adams, P. J.: Efficiency of cloud condensation nuclei formation from ultrafine particles, Atmos. Chem. Phys., 7, 1367-1379, doi:10.5194/acp-7-1367-2007, 2007.

Platnick, S. and S. Twomey: Determining the susceptibility of cloud albedo to changes in droplet concentration with the advanced very high resolution radiometer, J. Appl. Meteorol., 33, 334-347, 1994.

Quinn, P. K., Bates, T. S.: The case against climate regulation via oceanic phytoplankton sulphur emissions, Nature, 480, 51-56, doi:10.1038/nature10580, 2011.

Spracklen, D. V., Carslaw, K. S., Kulmala, M., Kerminen, V.-M., Sihto, S.-L., Riipinen, I., Merikanto, J., Mann, G. W., Chipperfield, M. P., Wiedensohler, A., Birmili, W., and Lihavainen, $\mathrm{H}$ : Contribution of particle formation to global cloud condensation nuclei concentrations, Geophys. Res. Lett., 35, L06808, doi:10.1029/2007GL033038, 2008.

Spracklen, D. V., Carslaw, K. S., Merikanto, J., Mann, G. W., Reddington, C. L., Pickering, S., Ogren, J. A., Andrews, E., Baltensperger, U., Weingartner, E., Boy, M., Kulmala, M., Laakso, L., Lihavainen, H., Kivekäs, N., Komppula, M., Mihalopoulos, N., Kouvarakis, G., Jennings, S. G., O’Dowd, C., Birmili, W., Wiedensohler, A., Weller, R., Gras, J., Laj, P., Sellegri, K., Bonn, B., Krejci, R., Laaksonen, A., Hamed, A., Minikin, A., Harrison, R. M., Talbot, R., and Sun, J.: Explaining global surface aerosol number concentrations in terms of primary emissions and particle formation, Atmos. Chem. Phys., 10, 4775-4793, doi:10.5194/acp-10-4775-2010, 2010.

Trivitayanurak, W., Adams, P. J., Spracklen, D. V., and Carslaw, K. S.: Tropospheric aerosol microphysics simulation with assimilated meteorology: model description and intermodel comparison, Atmos. Chem. Phys., 8, 3149-3168, doi:10.5194/acp-83149-2008, 2008.

Twomey, S.: The influence of pollution on the shortwave albedo of clouds, J. Atmos. Sci., 34, 1149-1152, 1977.

Vehkamäki, H., Kulmala, M., Napari, I., Lehtinen, K. E. J., Timmreck, C., Noppel, M., and Laaksonen, A.: An improved parameterization for sulfuric acid/water nucleation rates for tropospheric and stratospheric conditions, J. Geophys. Res., 107, 4622, doi:10.1029/2002JD002184, 2002.

Wang, M. and Penner, J. E.: Aerosol indirect forcing in a global model with particle nucleation, Atmos. Chem. Phys., 9, 239-260, doi:10.5194/acp-9-239-2009, 2009.
Weller, R. and Lampert, A.: Optical properties and sulfate scattering efficiency of boundary layer aerosol at coastal Neumayer Station, Antarctica, J. Geophys. Res., 113, D16208, doi:10.1029/2008JD009962, 2008.

Woodhouse, M. T., Carslaw, K. S., Mann, G. W., Vallina, S. M., Vogt, M., Halloran, P. R., and Boucher, O.: Low sensitivity of cloud condensation nuclei to changes in the sea-air flux of dimethyl-sulphide, Atmos. Chem. Phys., 10, 7545-7559, doi:10.5194/acp-10-7545-2010, 2010.

Yu, F.: Effect of ammonia on new particle formation: A kinetic $\mathrm{H}_{2} \mathrm{SO}_{4}-\mathrm{H}_{2} \mathrm{O}-\mathrm{NH}_{3}$ nucleation model constrained by laboratory measurements, J. Geophys. Res., 111, D01204, doi:10.1029/2005JD005968, 2006.

$\mathrm{Yu}, \mathrm{F}$.: Improved quasi-unary nucleation model for binary $\mathrm{H}_{2} \mathrm{SO}_{4}-$ $\mathrm{H}_{2} \mathrm{O}$ homogeneous nucleation, J. Chem. Phys., 127, 054301, doi:10.1063/1.2752171, 2007.

Yu, F.: Ion-mediated nucleation in the atmosphere: Key controlling parameters, implications, and look-up table, J. Geophy. Res., 115, D03206, doi:10.1029/2009JD012630, 2010.

Yu, F.: A secondary organic aerosol formation model considering successive oxidation aging and kinetic condensation of organic compounds: global scale implications, Atmos. Chem. Phys., 11, 1083-1099, doi:10.5194/acp-11-1083-2011, 2011.

Yu, F. and Luo, G.: Simulation of particle size distribution with a global aerosol model: contribution of nucleation to aerosol and CCN number concentrations, Atmos. Chem. Phys., 9, 76917710, doi:10.5194/acp-9-7691-2009, 2009.

Yu, F. and Turco, R. P.: The size-dependent charge fraction of sub-3-nm particles as a key diagnostic of competitive nucleation mechanisms under atmospheric conditions, Atmos. Chem. Phys., 11, 9451-9463, doi:10.5194/acp-11-9451-2011, 2011.

Yu, F., Luo, G., Bates, T., Anderson, B., Clarke, A., Kapustin, V., Yantosca, R., Wang, Y., and Wu, S.: Spatial distributions of particle number concentrations in the global troposphere: Simulations, observations, and implications for nucleation mechanisms, J. Geophys. Res., 115, D17205, doi:10.1029/2009JD013473, 2010.

Zhang, Q., Streets, D. G., Carmichael, G. R., He, K. B., Huo, H., Kannari, A., Klimont, Z., Park, I. S., Reddy, S., Fu, J. S., Chen, D., Duan, L., Lei, Y., Wang, L. T., and Yao, Z. L.: Asian emissions in 2006 for the NASA INTEX-B mission, Atmos. Chem. Phys., 9, 5131-5153, doi:10.5194/acp-9-5131-2009, 2009. 